\title{
Antibiotic resistance: a hospital-based multicenter study in Tabuk city, Kingdom of Saudi Arabia
}

This article was published in the following Dove Press journal:

Infection and Drug Resistance

\section{Umar Yagoub' \\ Bandar Al Qahtani ${ }^{2}$ \\ Ibrahim AL Hariri ${ }^{3}$ \\ Attiya Al Zahrani ${ }^{4}$ \\ Kashif Siddique'}

'Research Department, Academic Affairs, King Salman Armed Forces Hospital Northwestern Region, Tabuk 7/4II, Saudi Arabia; ${ }^{2}$ Department of Academic Affairs, King Salman Armed Forces Hospital Northwestern Region, Tabuk 7/4II, Saudi Arabia; ${ }^{3}$ Department of Family Medicine, King Salman Armed Forces Hospital Northwestern Region, Tabuk 7|4II, Saudi Arabia; ${ }^{4}$ Department of Surgery, King Salman Armed Forces Hospital Northwestern Region, Tabuk $7|4| 1$, Saudi Arabia
Correspondence: Umar Yagoub Research Department, Academic Affairs, King Salman Armed Forces Hospital Northwestern Region, Tabuk 7|4II, Saudi Arabia

Tel +9 66I 4441088 Ext 85818

Email mohammedumar200I@yahoo.com
Background: During the 21st century, antimicrobial resistance (AMR) has emerged as one of the greatest public health challenges worldwide. In the coming 20 years, health care systems may be unable to treat bacterial diseases efficiently due to this phenomenon.

Objective: To determine the level of knowledge regarding AMR among patients attending two hospitals in Tabuk city in northeast Kingdom of Saudi Arabia (KSA).

Materials and Methods: This cross-sectional study was conducted at King Salman Armed Forces Hospital and King Khalid Armed Forces Hospital in Tabuk city. The study participants were selected from different outpatient departments using a simple random sampling technique. Data collection was performed using a self-reported questionnaire. All of the questions were closed-ended to facilitate study participation and were translated into Arabic. The data were entered into SPSS version 22 for Windows, cleaned and managed before analysis.

Results: Our results showed that $26.85 \%$ of the respondents had knowledge regarding antibiotic resistance. Knowledge regarding the use of antibiotics for treating bacterial infection was good among participants $(60 \%)$, but responses related to viral infection indicated confusion $(23.06 \%)$, and misconceptions were observed. Several factors were significantly associated with knowledge regarding AMR among participants: 1) the use of antibiotics in the last year (OR: 2.102, CI: 0.654-6.754); 2) the discontinued use of antibiotics when feeling better (OR: 8.285, CI: 3.918-17.523); 3) giving antibiotics to friends or family members to treat the same illness ([False]: OR: 108.96, CI: 29.98-395.93) and 4) asking doctors to prescribe antibiotics that had been previously administered for the same symptoms (OR: 9.314, CI: 3.684-23.550).

Conclusion: Our results revealed a very high unawareness of AMR and its contributing factors among the study participants. Thus, health education and awareness are highly and urgently recommended to address AMR in the Tabuk area.

Keywords: antibiotic, resistance, knowledge, self-medication

\section{Introduction}

Antimicrobial resistance (AMR) has emerged as one of the most important challenges of public health care during the last 10 years and is considered to be one of the primary risks to human health. ${ }^{1,2}$ AMR is defined as the ability of a microorganism to survive or grow in the presence of a concentration of antibiotics that should be enough to restrain or kill that organism. ${ }^{3}$ In the coming 20 years, health care systems may be unable to treat bacterial diseases efficiently. ${ }^{4}$ Infections caused by multidrug-resistant microorganisms result in increased mortality, morbidity, and higher hospitalization rates as well as increased complications and health care costs. ${ }^{5}$ 
Exacerbating factors responsible for the development of AMR include poor knowledge, misconceptions, views on infectious diseases, inappropriate prescription and medication use and patient demand. ${ }^{6-10}$

Misconceptions regarding the therapeutic effects of antibiotics have shown that people consider antibiotics to be extraordinary medications that can be used to treat any infection caused by viruses, bacteria or fungi. ${ }^{11}$ Thus, the problem of AMR can be minimized if the general population possesses good knowledge of the appropriate use of antibiotics. $^{12}$

In the Middle East region, the Kingdom of Saudi Arabia is among the richest developing countries, and its population is multiethnic. ${ }^{13}$ In most of the government hospitals in Saudi Arabia, medication provision and doctor consultation are free, and self-medication with antibiotics and nondoctor prescriptions are very common in the community. There are many reasons for self-medication with antibiotics: if patients use particular antibiotics for specific signs and symptoms in the past, he may use the same antibiotics if he feels his current illness is similar to the one the past. Other reasons such as friend advice based on similar experience or if the pharmacy is near to the patients' resistance and the hospital is far from patients may encourage self-prescription with antibiotics. A bad doctor-patient relationship may also discourage doctor consultations and encourage self-medication with antibiotics, such as the distance to the hospital being too far or advice from friends with regards to self-medication with antibiotics leading to no other information being obtained. $^{13}$

Internationally, the KSA has been recognized as a country with escalating AMR, which is a concern for the Kingdom health authorities. ${ }^{14}$ According to the results of a previous study, the use of antibiotics without any prescriptions is quite frequent in the community, and antibiotics are used to treat inappropriate conditions. $^{15}$

The public has easy access to antibiotics, and the availability of antibiotics is uncontrolled in the KSA. This frequent and easy access to antibiotics changes the perspective of interventions initiated by the health authorities to control the irrational use of antibiotics that leads to AMR ${ }^{16,17}$ To date, very few studies have been reported on AMR in the KSA. However, the results of available studies have shown that there is very poor knowledge regarding antibiotic use and AMR among the general population. $^{13,17}$
To tackle the urgent issues surrounding AMR in Saudi Arabia, it is of vital importance to raise public awareness regarding this issue. A better understanding regarding the spread of AMR can encourage the general population to avoid practices and behaviors that spread antibiotic resistance. $^{18}$

In the KSA, there is no national surveillance system of AMR and health care-acquired infections. To date, no study has been conducted in Tabuk (North Western region) to assess the knowledge and awareness of people regarding antibiotic resistance. Therefore, the results of this study will provide data concerning the knowledge regarding AMR in Tabuk. In addition, this study will help the medical service division in planning and formulating new educational strategies and interventions to promote the appropriate use of antibiotics among the general population to minimize the escalating rate of AMR in this region. Therefore, we designed this study to determine the level of knowledge regarding AMR in the general population in Tabuk city. The locality of the study is shown in Figure 1.

\section{Materials and methods}

\section{Study design, sample size calculation and sampling}

This was a hospital-based cross-sectional study that was conducted in King Salman Armed Forces Hospital and King Khalid Armed Forces Hospital in Tabuk City between November 2016 and October 2017. The inclusion criteria for the study participants were that they be adults (either sex, male or female) and Saudi nationals who willingly agreed to participate in the study. Those who refused to participate, could not read the study questionnaire, were below 18 years of age or refused to participate were excluded from the study. Verbal consent to participate in the study was obtained prior to the start of the study, and parents or legal guardian of any participant under the age of 18 years provided this consent. The sample size was collected from the two hospitals mentioned above which are the main hospitals in the city of Tabuk. The outpatient departments in the two hospitals are the main areas where most of the patients are seen for treatment and follow-up. The sample size was based on a single proportion using the following formula adopted from Cochran (1977).

$$
\mathrm{n}=\frac{Z^{2} p(1-p)}{\mathrm{d}^{2}}
$$

n: the sample size $=1,066$ 


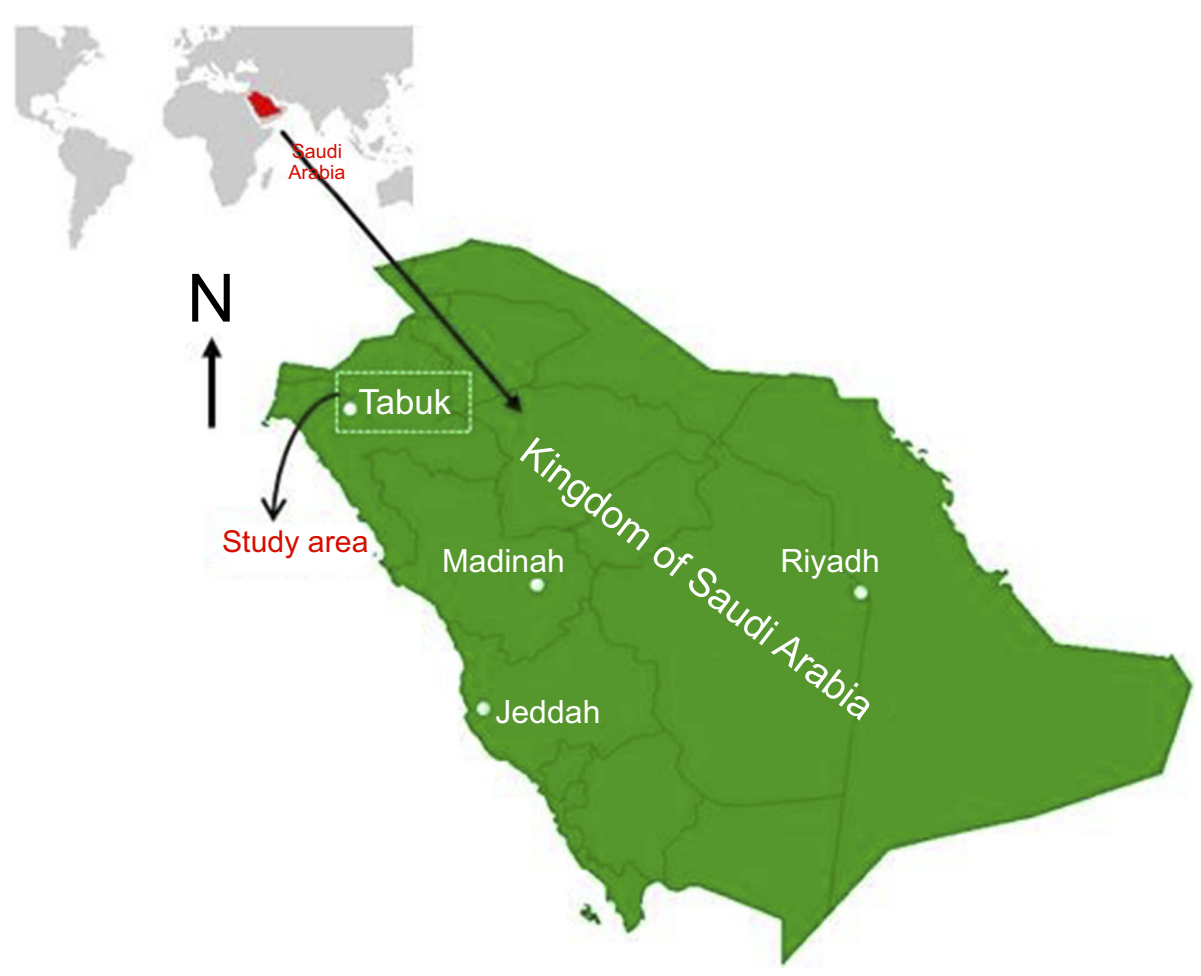

Figure I Study area location.

p: the probability of success (ie, AMR knowledge) $=47.9 \%$

$\mathrm{Z}$ : the standardized variable that corresponds to a $95 \%$ level of confidence $=95 \%$

$\mathrm{d}$ : the desired marginal error $=3 \%$

According to this formula, knowledge regarding AMR in Saudi Arabia was reported as $47.9 \%{ }^{17}$ Using this percentage and other parameters in the formula, the calculated sample size was 1,066. Additionally, it is important to consider the nonresponse rate, which we suggest was $20 \%$ of the total recruitment number $(1,066)$, yielding a value of 213 . The total sample size was 1,279 participants.

The study participants were selected from a range of different outpatient departments from King Salman Armed Forces Hospital and King Khaled Armed Forces Hospital which are now one hospital under the same administration using a simple random sampling technique by a trained research assistant. This is done through a computergenerated process in which each of the patients is assigned a number, after which the requested sample would be chosen at random. The dependent variable (AMR knowledge among study participants) and independent variables (sociodemographic characteristics, factors leading to antibiotic resistance, different diseases that can be treated with antibiotics and problems of antibiotic resistance) were recorded.

\section{Study instrument and data collection}

The self-reported study questionnaire was developed following an extensive literature review of similar studies, and the AMR report published by the WHO was also used. The questionnaire consisted of two parts. The first part included sociodemographic characteristics and the second part consisted of three sections: the use of antibiotics, participants' general knowledge about antibiotics and participants' knowledge about antibiotic resistance. All of the questions were close-ended. The study questionnaire was forward and backward translated from English into Arabic with the help of a bilingual translator. The pretested and validated study instrument was first pilot-tested on 20 participants and then administered to the study participants who fulfilled the inclusion criteria by research assistants. Before analysis, the data were entered into SPSS IBM version 22 for Windows, cleaned and preprocessed, which involved accuracy checking, treatment of missing values and categorization of study variables.

\section{Data analysis and modeling}

Data analysis was performed using SPSS version 22. Quantitative variables are presented as means \pm SDs. 
Qualitative variables are presented using frequency tables and percentages. Multiple logistic regression was used to identify the factors associated with antibiotic resistance. All of the statistical values were considered significant at $P \leq 0.05$. Only the results of multivariate logistic analyses are reported, showing ORs and $95 \% \mathrm{CI}$.

\section{Ethical approval}

Ethical approval was obtained from the Research Ethical Committee of King Salam Armed Forces Hospital under project number RREC2016-145. The Research Ethical Committee also covers King Khalid Armed Forces Hospital. Verbal informed consent was acceptable and approved by the approving research ethics committee.

\section{Results}

Of the 1,279 participants, 1,188 completed questionnaires without any missing values after data cleaning and management. The response rate was $93 \%$.

Table 1 shows the sociodemographic characteristics of the study participants, while Figure 2 shows the responses of participants regarding the use of antibiotics for treating certain conditions. The top 5 common conditions for which antibiotics were used were urinary tract infection (UTI), diarrhea, sore throat, gonorrhea and skin or wound infection, whereas the least common conditions were headache, HIV/AIDS, cold and flu and measles. Figure 3 shows the knowledge of participants regarding AMR terminology, while Table 2 shows the knowledge of participants regarding antibiotic resistance. Only $10.2 \%$ of participants knew that AMR develops when bacteria become resistant to antibiotics, $17.6 \%$ of participants knew that it is difficult to cure an infection in the presence of antibiotic resistant bacteria and $25 \%$ of respondents knew that surgical procedures are dangerous during an AMR infection. Furthermore, $32.4 \%$ of respondents told us that they used antibiotics for the duration prescribed by the doctor, while $24.1 \%$ of respondents reported that they stopped taking antibiotics before the end of the treatment.

The results of the multiple logistic regression analysis (Table 4) revealed that several factors showed a significant association with the knowledge of the participants regarding antibiotic resistance (Table 3): age; region; education; monthly income; nationality; job status; use of antibiotics (in the last 6 months and more than a year ago); time of prescription; time during the antibiotic course when participants stopped taking antibiotics; giving antibiotics to a friend or family member as long as the antibiotics were
Table I Demographic characteristics of the study participants $(n=I, 188)$

\begin{tabular}{|c|c|c|}
\hline Characteristics & $\mathbf{n}$ & $\begin{array}{l}\text { Percentage } \\
(\%)\end{array}$ \\
\hline \multicolumn{3}{|l|}{ Age (years) } \\
\hline $16-24$ & 297 & 25.0 \\
\hline $25-33$ & 389 & 32.7 \\
\hline $34-42$ & 385 & 32.4 \\
\hline $43-51$ & 59 & 5.0 \\
\hline $52-60$ & 58 & 4.9 \\
\hline Total & 1,188 & 100 \\
\hline \multicolumn{3}{|l|}{ Sex } \\
\hline Male & 913 & 76.9 \\
\hline Female & 275 & 23.1 \\
\hline Total & 1,188 & 100 \\
\hline \multicolumn{3}{|l|}{ Residence } \\
\hline Tabuk city & 935 & 78.7 \\
\hline Rural side of Tabuk city & 253 & 21.3 \\
\hline Total & 1,188 & 100 \\
\hline \multicolumn{3}{|l|}{ Education } \\
\hline No formal schooling & 78 & 6.6 \\
\hline 12 th grade or less & 166 & 14.0 \\
\hline High school graduate with diploma & 366 & 30.8 \\
\hline $\begin{array}{l}\text { Technical/vocational training or associate } \\
\text { degree }\end{array}$ & 198 & 16.7 \\
\hline $\begin{array}{l}\text { University graduate with bachelor's } \\
\text { degree }\end{array}$ & 253 & 21.3 \\
\hline Postgraduate degree & 126 & 10.7 \\
\hline Total & 1,188 & 100 \\
\hline \multicolumn{3}{|l|}{ Monthly income (SR) } \\
\hline$\leq 5,000$ & 143 & 12.0 \\
\hline $5,00 \mathrm{I}-\mathrm{I}, 000$ & 242 & 20.4 \\
\hline $10,001-15,000$ & 330 & 27.8 \\
\hline$\geq 15,000$ & 473 & 39.8 \\
\hline Total & I, I88 & $100 \%$ \\
\hline \multicolumn{3}{|l|}{ Nationality } \\
\hline Saudi & $\mathrm{I}, 078$ & 90.7 \\
\hline Non-Saudi & 110 & 9.3 \\
\hline Total & I,I88 & 100 \\
\hline \multicolumn{3}{|l|}{ Job status } \\
\hline Not employed & 924 & 77.8 \\
\hline Employed & 99 & 8.3 \\
\hline Retired & 165 & 13.9 \\
\hline Total & I, I88 & 100 \\
\hline
\end{tabular}

used to treat the same illness; and buying the same antibiotics from a doctor if the participant was sick and the 


\section{Knowledge of conditions that can be treated with} antibiotics

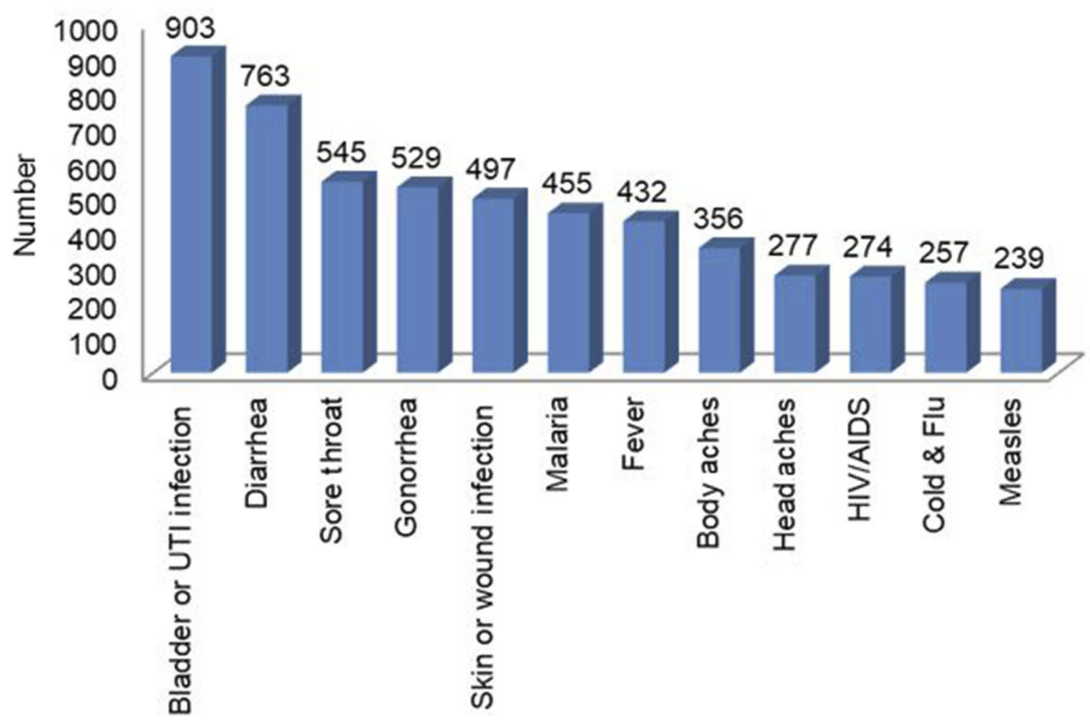

Figure 2 Participants' knowledge of conditions that can be treated with antibiotics.

Knowledge regarding antibiotic resistance terms

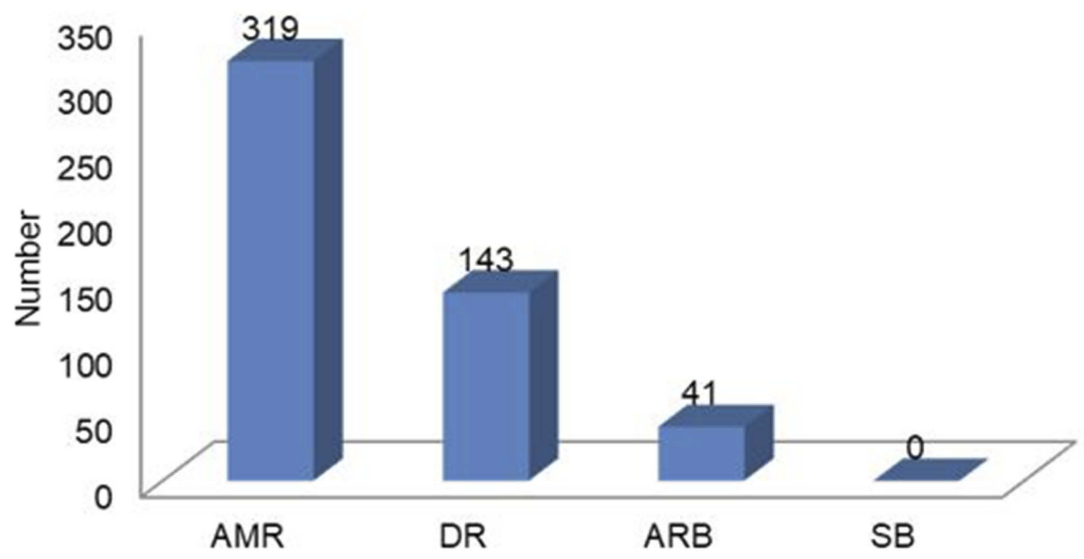

Figure 3 Participants' knowledge regarding antimicrobial resistance.

Abbreviations: AMR, antimicrobial resistance; DR, drug resistance; ARB, antibiotic resistant bacteria; SB, superbugs (multidrug resistance bacteria).

same antibiotics had helped the participant recover from the same symptoms. Before multiple logistic regression analysis, all possible confounding variables were considered.

\section{Discussion}

The primary objective of this study was to determine the level of knowledge regarding AMR among study participants in two major hospitals in Tabuk city. One of the most important steps in combating AMR is augmenting the knowledge of the general public.
In this study, only $26.85 \%$ of the respondents had knowledge regarding antibiotic resistance, which is very low compared to the results of a similar study conducted in other parts of the kingdom. In contrast to this study, a higher percentage of knowledge regarding AMR was reported from South Korea, ${ }^{19}$ Kuwait $(45.4 \%),{ }^{20}$ and Saudi Arabia and Jordan $(60.7 \%){ }^{21}$ Compared to these studies, studies from Hong Kong (91\%) and Indonesia $(85 \%)$ showed a greater knowledge of respondents for the term antibiotic resistance. ${ }^{11,22}$ In contrast, an Italian 
Table 2 Factors related to antibiotic use by study participants $(n=I, I 88)$

\begin{tabular}{|c|c|c|}
\hline \multicolumn{3}{|l|}{ When did you last use antibiotics? } \\
\hline In the last month & 869 & $73.1 \%$ \\
\hline In the last 6 months & 110 & $9.3 \%$ \\
\hline In the last year & 99 & $8.3 \%$ \\
\hline More than a year ago & 77 & $6.5 \%$ \\
\hline Never & 33 & $2.8 \%$ \\
\hline Total & 1.188 & $100 \%$ \\
\hline \multicolumn{3}{|l|}{ From where did you get the antibiotics? } \\
\hline Medical store or pharmacy & 891 & $75.0 \%$ \\
\hline Stall or hawker & 154 & $13.0 \%$ \\
\hline From the internet & 99 & $8.3 \%$ \\
\hline Friend or family member & 44 & $3.7 \%$ \\
\hline Total & 1,188 & $100 \%$ \\
\hline \multicolumn{3}{|l|}{ When did you stop taking these antibiotic? } \\
\hline When I felt better & 254 & $21.4 \%$ \\
\hline When I had taken all of the antibiotics as directed & 378 & $31.8 \%$ \\
\hline I don't know & 556 & $46.8 \%$ \\
\hline Total & 1,188 & $100 \%$ \\
\hline \multicolumn{3}{|c|}{$\begin{array}{l}\text { "Using antibiotics that were given to a friend or family member, as } \\
\text { long as they were used to treat the same illness, is a correct practice." }\end{array}$} \\
\hline True & 480 & $40.4 \%$ \\
\hline False & 299 & $25.2 \%$ \\
\hline Don't know & 409 & $34.4 \%$ \\
\hline Total & 1,188 & $100 \%$ \\
\hline \multicolumn{3}{|c|}{$\begin{array}{l}\text { It's okay to use the same antibiotics which were used to treat the } \\
\text { same symptoms in the past }\end{array}$} \\
\hline True & 649 & $54.6 \%$ \\
\hline False & 539 & $45.4 \%$ \\
\hline Total & I, 188 & $100 \%$ \\
\hline
\end{tabular}

study showed a lower level of knowledge among study participants (ie, 9.8\% knew the definition of antibiotic resistance). ${ }^{23}$ The above-discussed studies showed inconsistencies in the knowledge of populations regarding the AMR in different regions.

In this study, the knowledge of the study participants was good regarding the use of antibiotics for treating bacterial infection, but when queried regarding viral infection, the study population exhibited confusion and misconception. Over $60 \%$ of the respondents knew that antibiotics can be effectively used to treat bacterial infections. However, only one-fourth of the study population reported that antibiotics cannot be used to treat viral infections, showing that the respondents were not well aware that antibiotics have no therapeutic effect toward viral diseases. The same findings were reported in studies from Kuwait and Malaysia. ${ }^{20,24,25}$ In contrast to the findings of this study, a higher level of awareness regarding the appropriate use of antibiotics was reported in studies from the UK, Sweden, Jordan and European countries. $^{7,21,26}$ The results of studies from Sweden and Kuwait confirm the confusion among the public regarding whether antibiotics are effective against bacteria or viruses. ${ }^{7,20}$

In this study, $22-46 \%$ of the study participants used antibiotics to treat cold/flu (22\%), fever (36\%) and sore throats $(46 \%)$. These findings are comparable with those reported in studies from the USA ${ }^{27}$ and Poland. ${ }^{28}$ In contrast, a higher proportion of participants used antibiotics to treat a cold, flu, fever and sore throat in studies from Namibia, Nigeria and Jordan. ${ }^{21,29,30}$

As discussed above, it is evident that the general population lacks proper knowledge regarding the appropriate use of antibiotics and the meaning of antibiotic resistance.

Females were 0.74 times (95\% CI 0.42-1.30) more likely to be aware of AMR than were the male participants. Participants in the 16- to 18- and 25- to 34-year-old age groups had the highest awareness regarding antibiotic resistance. Literature reported that knowledge of AMR increased with age, ${ }^{31}$ a trend that was observed in this study.

Various studies around the world have concluded that a lack of knowledge regarding AMR is associated with lower education. 7,9,24,32 $^{2}$

In his study, Francesco Napolitano identified a lower educational level and unemployment as being significantly associated with not knowing the definition of antibiotic resistance. ${ }^{23}$ In contrast to this study, participants with a lower education and an unemployed status were more likely to be aware of antibiotic resistance. The finding of Tatyana Belkina regarding education and knowledge concerning AMR is consistent with the findings of this study, as he has shown that more educated respondents were less knowledgeable regarding bacterial resistance in Yemen. ${ }^{31}$

Various studies across the globe have reported that age, gender and educational level are recognized as potential factors that influence attitudes toward antibiotics. ${ }^{9,18,23,33}$

The following factors were significantly associated with AMR knowledge among participants: participants who used antibiotics in the last year (OR: 2.102, CI: 0.654-6.754), discontinued antibiotics upon feeling better (OR: 8.285 , CI: 3.918-17.523), gave antibiotics to friends or family members to treat the same illness ([False]: OR: 108.96, CI: 29.98-395.93) and participants who asked their doctors to prescribe 
Table 3 Knowledge regarding AMR $(n=1,188)$

\begin{tabular}{|c|c|c|c|c|c|}
\hline No. & Questions & Yes & No & $\begin{array}{l}\text { I don't } \\
\text { know }\end{array}$ & Total \\
\hline I & It occurs when antibiotic treatments do not work in the body & $121(10.2 \%)$ & $792(66.7 \%)$ & $275(23.1 \%)$ & $\mathrm{I}, 188$ \\
\hline 2 & When antibiotics do not treat infection & $209(17.6 \%)$ & $880(74.1 \%)$ & $99(8.3 \%)$ & $\mathrm{I}, 188$ \\
\hline 3 & Bacteria resistant to antibiotics are difficult to treat & $99(8.3 \%)$ & $1,056(88.9 \%)$ & $33(2.8 \%)$ & $\mathrm{I}, \mathrm{I} 88$ \\
\hline 4 & AMR can affect me and my family & $44(3.7 \%)$ & I,023 (86.1\%) & $12 \mathrm{I}(10.2 \%)$ & $\mathrm{I}, 188$ \\
\hline 5 & AMR is an issue in other countries but not here & $704(59.3 \%)$ & $45 \mathrm{I}(38 \%)$ & $33(2.8 \%)$ & $\mathrm{I}, 188$ \\
\hline 6 & A problem for people who take antibiotics regularly & $385(32.4 \%)$ & $770(64.8 \%)$ & $33(2.8 \%)$ & $\mathrm{I}, 188$ \\
\hline 7 & Bacteria resistant to antibiotics can spread person to person & $198(16.7 \%)$ & $924(77.8 \%)$ & $66(5.6 \%)$ & 1,188 \\
\hline 8 & AMR infections could make medical procedures more dangerous & $297(25 \%)$ & $803(67.6 \%)$ & $88(7.4 \%)$ & 1,188 \\
\hline 9 & People should use antibiotics only when prescribed by doctors & $319(26.9 \%)$ & $638(53.7 \%)$ & $231(19.4 \%)$ & 1,188 \\
\hline 10. & People should not keep antibiotics and use them later for other illnesses & $946(79.6 \%)$ & $66(5.6 \%)$ & $176(14.8 \%)$ & $\mathrm{I}, \mathrm{I} 88$ \\
\hline II & AMR is one of the biggest problems the world faces & $671(56.5 \%)$ & $418(35.2 \%)$ & $99(8.3 \%)$ & $\mathrm{I}, 188$ \\
\hline 12 & There is not much people like me can do to stop AMR & $0(0 \%)$ & $924(77.8 \%)$ & $264(22.2 \%)$ & $\mathrm{I}, 188$ \\
\hline 13 & Governments should reward the development of new antibiotics & $\mathrm{I}, 078(90.7 \%)$ & 99 (8.3\%) & II $(0.9 \%)$ & $\mathrm{I}, \mathrm{I} 88$ \\
\hline 14 & Pharmaceutical companies should develop new antibiotics & $231(19.4 \%)$ & $913(76.9 \%)$ & $44(3.7 \%)$ & 1,188 \\
\hline 15 & $\begin{array}{l}\text { Patients should use antibiotics for the entire period described by the } \\
\text { doctor }\end{array}$ & $198(16.7 \%)$ & $913(76.9 \%)$ & 77 (6.5\%) & 1,188 \\
\hline 16 & Do you stop the antibiotic before the prescribed period? & $385(32.4 \%)$ & $748(63 \%)$ & 55 (4.6\%) & 1,188 \\
\hline 17 & $\begin{array}{l}\text { Failure to comply with the prescribed duration of treatment (antibiotics) } \\
\text { can result in AMR }\end{array}$ & $286(24.1 \%)$ & 825 (69.4\%) & 77 (6.5\%) & 1,188 \\
\hline 18 & $\begin{array}{l}\text { Do you think that you should tell your doctor all the antibiotics that have } \\
\text { already been taken previously? }\end{array}$ & $429(36.1 \%)$ & 704 (59.3\%) & 55 (4.6\%) & $\mathrm{I}, \mathrm{I} 88$ \\
\hline 19 & $\begin{array}{l}\text { Have you ever used a particular antibiotic and then the use of the same } \\
\text { antibiotic in a subsequent period did not improve symptoms? }\end{array}$ & 374 (31.5\%) & 759 (63.9\%) & 55 (4.6\%) & 1,188 \\
\hline
\end{tabular}

Abbreviation: AMR, antimicrobial resistance.

previously administered antibiotics for the same symptoms (OR:9.314, CI: 3.684-23.550).

Social factors, such as misconceptions regarding antibiotics, poor knowledge regarding infectious diseases, improper prescribing and use of antibiotics, overprescription of antibiotics at patient demand, nonadherence and self-medication, escalate the development of antibiotic resistance. Therefore, it is of vital importance that public health specialists and health care providers offer instruction to the community regarding the understanding and appropriate use of antibiotics.

Our study had serval limitations such as recall bias which was minimized by adapting a well-formatted, simple and easy-to-understand questionnaire and selection bias which was minimized by using appropriate sampling technique. One of the limitations is the study population is limited to the two major hospitals and not all the populations of the city. Using multicenter for data collection is strength of this study.

It is important for the benefit of society that the general public and individuals can understand the AMR phenomenon and minimize/control activities that result in the spread of antibiotic resistance. Behavioral interventions are of core importance to minimize the phenomenon of antibiotic resistance.

To correct the extensive misconceptions regarding antibiotic use, reliable and multifaceted interventions are needed to promote the appropriate use of antibiotics and deal with problems regarding antibiotic resistance. To effectively control and prevent antibiotic resistance, public health interventions are considered to be one of the most successful strategies that can promote the appropriate use of antibiotics.

\section{Conclusions}

The results of this study demonstrated that the people of Tabuk are not well informed regarding AMR and its contributing factors. Furthermore, the study participants had many misconceptions regarding the use of antibiotics. Thus, this situation requires urgent educational intervention campaigns that can provide assistance to promote an awareness of the appropriate use of antibiotics in both king Salman and King Khalid Hospital in Tabuk. The Ministry of Health in Tabuk city should take 
Table 4 Demographic characteristics, knowledge and practice of participants regarding antibiotics in relation to antimicrobial resistance (AMR) knowledge

\begin{tabular}{|c|c|c|c|c|c|c|c|}
\hline \multirow[t]{2}{*}{ Predictors } & \multicolumn{3}{|c|}{ DV: Knowledge of AMR } & \multirow[t]{2}{*}{ OR } & \multirow{2}{*}{\multicolumn{2}{|c|}{$95 \% \mathrm{Cl}$}} & \multirow[t]{2}{*}{$p$-value } \\
\hline & Yes & No & Total & & & & \\
\hline \multicolumn{8}{|l|}{ Sex } \\
\hline Male & 253 & 660 & 913 & 0.742 & 0.42 & 1.30 & 0.302 \\
\hline Female & 66 & 209 & 275 & $\mathrm{I}$ & - & - & - \\
\hline Total & 319 & 869 & 1188 & & & & \\
\hline \multicolumn{8}{|l|}{ Age group (years) } \\
\hline $16-18$ & 77 & 220 & 297 & 6.405 & 2.33 & 17.55 & 0.000 \\
\hline $19-24$ & 82 & 307 & 389 & 2.730 & 1.03 & 7.23 & 0.043 \\
\hline $25-34$ & 143 & 242 & 385 & 9.299 & 3.34 & 25.86 & 0.000 \\
\hline $35-44$ & 10 & 49 & 59 & 2.785 & 0.83 & 9.34 & 0.097 \\
\hline $45-54$ & 7 & 51 & 58 & 1 & - & - & - \\
\hline Total & 319 & 869 & 1188 & & & & \\
\hline \multicolumn{8}{|l|}{ Region } \\
\hline Tabuk city & 253 & 682 & 935 & 0.456 & 0.26 & 0.78 & 0.004 \\
\hline Rural side of Tabuk city & 66 & 187 & 253 & I & - & - & - \\
\hline Total & 319 & 869 & 1188 & & & & \\
\hline \multicolumn{8}{|l|}{ Education } \\
\hline Not educated & 22 & 56 & 78 & 31.045 & 8.24 & 116.91 & 0.000 \\
\hline Primary & 77 & 89 & 166 & 14.025 & 4.42 & 44.45 & 0.000 \\
\hline Middle & 108 & 258 & 366 & 6.198 & 2.06 & 18.59 & 0.001 \\
\hline Secondary & 55 & 143 & 198 & 3.162 & 1.01 & 9.88 & 0.048 \\
\hline Diploma & 22 & 231 & 253 & 0.265 & 0.07 & 0.91 & 0.035 \\
\hline Bachelor's degree & 29 & 52 & 81 & 5.048 & 1.72 & 14.79 & 0.003 \\
\hline Master's degree & 6 & 40 & 46 & 1 & - & - & - \\
\hline Total & 319 & 869 & 1188 & & & & \\
\hline \multicolumn{8}{|c|}{ Monthly Income (Saudi riyals) } \\
\hline$\leq 5000$ & 44 & 99 & 143 & 0.085 & 0.023 & 0.306 & 0.000 \\
\hline $500 \mathrm{I}-1000$ & 66 & 176 & 242 & 0.028 & 0.007 & 0.109 & 0.000 \\
\hline $1000 I-15000$ & 88 & 242 & 330 & 0.327 & 0.177 & 0.605 & 0.000 \\
\hline$\geq 15000$ & 121 & 352 & 473 & I & - & - & - \\
\hline Total & 319 & 869 & 1188 & & & & \\
\hline \multicolumn{8}{|l|}{ Nationality } \\
\hline Saudi & 264 & 814 & 1078 & 0.105 & 0.046 & 0.236 & 0.000 \\
\hline NonSaudi & 55 & 55 & 110 & 1 & - & - & - \\
\hline Total & 319 & 869 & 1188 & & & & \\
\hline \multicolumn{8}{|l|}{ Job Status } \\
\hline Not employed & 242 & 682 & 924 & 5.693 & 2.997 & 10.816 & 0.000 \\
\hline Employed & 33 & 66 & 99 & 3.290 & 1.388 & 7.797 & 0.007 \\
\hline Retired & 44 & $|2|$ & 165 & I & - & - & \\
\hline Total & 319 & 869 & 1188 & & & & \\
\hline
\end{tabular}

(Continued) 
Table 4 (Continued).

\begin{tabular}{|c|c|c|c|c|c|c|c|}
\hline \multirow[t]{2}{*}{ Predictors } & \multicolumn{3}{|c|}{ DV: Knowledge of AMR } & \multirow[t]{2}{*}{ OR } & \multirow{2}{*}{\multicolumn{2}{|c|}{$95 \% \mathrm{Cl}$}} & \multirow[t]{2}{*}{$p$-value } \\
\hline & Yes & No & Total & & & & \\
\hline In the last month & 231 & 638 & 869 & 0.314 & 0.116 & 0.846 & 0.022 \\
\hline In the last 6 months & 33 & 77 & 100 & 0.438 & 0.136 & 1.407 & 0.165 \\
\hline In the last year & 33 & 66 & 99 & 2.102 & 0.654 & 6.754 & 0.212 \\
\hline More than a year ago & II & 66 & 77 & 0.128 & 0.030 & $0.54 I$ & 0.005 \\
\hline Never & 11 & 22 & 33 & 1 & - & - & - \\
\hline Total & 319 & 869 & 1188 & & & & \\
\hline \multicolumn{8}{|c|}{ Where did you get the antibiotics from? } \\
\hline Medical store/ Pharmacy & 253 & 638 & 891 & 0.218 & 0.070 & 0.676 & 0.008 \\
\hline Stall or hawker & 33 & 121 & 154 & 0.023 & 0.006 & 0.083 & 0.000 \\
\hline The internet & 22 & 77 & 99 & 0.014 & 0.003 & 0.067 & 0.000 \\
\hline Friend or family member & 11 & 33 & 44 & 1 & - & - & - \\
\hline Total & 319 & 869 & 1188 & & & & \\
\hline \multicolumn{8}{|c|}{ Stop taking antibiotics once you've begun treatment } \\
\hline When I feel better & 94 & 160 & 254 & 8.285 & 3.918 & 17.523 & 0.000 \\
\hline When taken all antibiotics as directed & 83 & 295 & 378 & 2.648 & 1.226 & 5.721 & 0.013 \\
\hline Don't know & 142 & 414 & 556 & 1 & - & - & - \\
\hline Total & 319 & 869 & 1188 & & & & \\
\hline \multicolumn{8}{|c|}{ "Use antibiotics that were given to a friend or family member, as long as they were used to treat the same illness" } \\
\hline True & 119 & 361 & 480 & 0.40 & 0.16 & 0.96 & 0.042 \\
\hline False & 108 & 191 & 299 & 108.96 & 29.98 & 395.93 & 0.000 \\
\hline Don't Know & 92 & 317 & 409 & 1 & - & - & - \\
\hline Total & 319 & 869 & 1188 & & & & \\
\hline \multicolumn{8}{|c|}{$\begin{array}{l}\text { It's okay to buy the same antibiotics from a doctor, if you're sick and they helped you get better when you had the same } \\
\text { symptoms before }\end{array}$} \\
\hline True & 163 & 486 & 649 & 9.314 & 3.684 & 23.550 & 0.000 \\
\hline False & 156 & 383 & 539 & 1 & - & & - \\
\hline Total & 319 & 869 & 1188 & & & & \\
\hline
\end{tabular}

Note: A p-value $\leq 0.05$ was considered significant.

strong action and enforce strict policies regarding dispensation of medications without prescription. In addition, physicians in both hospitals must also play a role in providing information to their patients so that they can adopt positive behaviors regarding the cautious use of antibiotics.

\section{Informed consent}

Informed consent was obtained from all the participants included in the study.

\section{Acknowledgments}

The authors are very grateful for the generous support provided by the Department of Academic Affairs, King
Salman Armed Forces Hospital North Western Region, Tabuk city, Saudi Arabia. The authors appreciate the dedicated efforts made by Mr. Marwan Manajreh during the data collection and entry processes. The authors would also like to thank Ms. Sunu Krishnan for her administrative assistance support during the study. This study was fully sponsored by the Department of Academic Affairs of the King Salman Armed Forces Hospital North Western Region, Tabuk, KSA.

\section{Disclosure}

The authors have no conflicts of interests to declare in this work. 


\section{References}

1. Viens A, Littmann J. Is antimicrobial resistance a slowly emerging disaster? Public Health Ethics. 2015;8(3):255-265. doi:10.1093/phe/ phv015

2. Hwang AY, Gums JG. The emergence and evolution of antimicrobial resistance: impact on a global scale. Bioorg Med Chem. 2016;24 (24):6440-6445. doi:10.1016/j.bmc.2016.04.027

3. Sabtu N, Enoch D, Brown N. Antibiotic resistance: what, why, where, when and how? Br Med Bull. 2015;116(1):1093.

4. Davies DS, Grant J, Catchpole M. The Drugs Don't Work: A Global Threat. UK: Penguin; 2013.

5. Ciorba V, Odone A, Veronesi L, Pasquarella C, Signorelli C. Antimicrobial resistance as a major public health concern: epidemiology and economic impact. Ann Ig. 2014;27(3):562-579.

6. Grigoryan L, Burgerhof JG, Degener JE, et al. Attitudes, beliefs and knowledge concerning antibiotic use and self-medication: a comparative European study. Pharmacoepidemiol Drug Saf. 2007;16(11):1234-1243. doi:10.1002/pds. 1479

7. André M, Vernby Å, Berg J, Lundborg CS. A survey of public knowledge and awareness related to antibiotic use and resistance in Sweden. J Antimicrob Chemother. 2010;65(6):1292-1296. doi:10.1093/jac/ dkq104

8. Sawalha AF. Self-medication with antibiotics: a study in Palestine. Int J Risk Saf Med. 2008;20(4):213-222.

9. You J, Yau B, Choi K, Chau C, Huang Q, Lee S. Public knowledge, attitudes and behavior on antibiotic use: a telephone survey in Hong Kong. Infection. 2008;36(2):153-157. doi:10.1007/s15010-007-7214-5

10. Harbarth S, Samore MH. Antimicrobial resistance determinants and future control. Emerg Infect Dis. 2005;11(6):794. doi:10.3201/ eid1106.050167

11. Widayati A, Suryawati S, de Crespigny C, Hiller JE. Knowledge and beliefs about antibiotics among people in Yogyakarta City Indonesia: a cross sectional population-based survey. Antimicrob Resist Infect Control. 2012;1(1):38. doi:10.1186/2047-2994-1-38

12. Gualano MR, Gili R, Scaioli G, Bert F, Siliquini R. General population's knowledge and attitudes about antibiotics: a systematic review and meta-analysis. Pharmacoepidemiol Drug Saf. 2015;24(1):2-10. doi:10.1002/pds.3716

13. Al Rasheed A, Yagoub U, Alkhashan H, et al. Prevalence and predictors of self-medication with antibiotics in Al Wazarat health center, Riyadh City, KSA. Biomed Res Int. 2016;2016:1-8. doi:10.1155/ 2016/3916874

14. Pablos-Méndez A, Raviglione MC, Laszlo A, et al. Global surveillance for antituberculosis-drug resistance, 1994-1997. N Engl J Med. 1998;338(23):1641-1649. doi:10.1056/NEJM199806043382301

15. Zowawi HM, Balkhy HH, Walsh TR, Paterson DL. $\beta$-Lactamase production in key gram-negative pathogen isolates from the Arabian Peninsula. Clin Microbiol Rev. 2013;26(3):361-380. doi:10.1128/CMR.00096-12

16. Emeka PM, Al-Omar M, Khan TM. Public attitude and justification to purchase antibiotics in the Eastern region Al Ahsa of Saudi Arabia. Saudi Pharm J. 2014;22(6):550-554. doi:10.1016/j.jsps.2014.02.014

17. El Zowalaty ME, Belkina T, Bahashwan SA, et al. Knowledge, awareness, and attitudes toward antibiotic use and antimicrobial resistance among Saudi population. Int J Clin Pharm. 2016;38 (5):1261-1268. doi:10.1007/s11096-016-0362-x
18. Vallin M, Polyzoi M, Marrone G, Rosales-Klintz S, Wisell KT, Lundborg CS. Knowledge and attitudes towards antibiotic use and resistance-A latent class analysis of a swedish population-based sample. PLoS One. 2016;11(4):e0152160. doi:10.1371/journal. pone. 0152160

19. Kim SS, Moon S, Kim EJ. Public knowledge and attitudes regarding antibiotic use in South Korea. J Korean Acad Nurs. 2011;41 (6):742-749. doi:10.4040/jkan.2011.41.6.742

20. Awad AI, Aboud EA. Knowledge, attitude and practice towards antibiotic use among the public in Kuwait. PLoS One. 2015;10(2): e0117910. doi:10.1371/journal.pone.0117910

21. Shehadeh M, Suaifan G, Darwish RM, Wazaify M, Zaru L, Alja'fari S. Knowledge, attitudes and behavior regarding antibiotics use and misuse among adults in the community of Jordan. A Pilot Study.. Saudi Pharm J. 2012;20(2):125-133. doi:10.1016/j.jsps.2011.11.005

22. Wun Y, Lam T, Lam K, Sun K. Antibiotic use: do parents act differently for their children? Int $J$ Clin Pract. 2012;66 (12):1197-1203. doi:10.1111/j.1742-1241.2012.03013.x

23. Napolitano F, Izzo MT, Di Giuseppe G, Angelillo IF. Public knowledge, attitudes, and experience regarding the use of antibiotics in Italy. PLoS One. 2013;8(12):e84177. doi:10.1371/journal. pone. 0084177

24. Oh AL, Hassali MA, Al-Haddad MS, Sulaiman SAS, Shafie AA, Awaisu A. Public knowledge and attitudes towards antibiotic usage: a cross-sectional study among the general public in the state of Penang, Malaysia. J Infect Dev Ctries. 2010;5(05):338-347.

25. Lim KK, Teh CC. A cross sectional study of public knowledge and attitude towards antibiotics in Putrajaya, Malaysia. South Med Rev. 2012;5(2):26.

26. McNulty CA, Boyle P, Nichols T, Clappison P, Davey P. Don't wear me out - the public's knowledge of and attitudes to antibiotic use. J Antimicrob Chemother. 2007;59(4):727-738. doi:10.1093/jac/dk1558

27. Carter RR, Sun J, Jump RL, editors. A Survey and Analysis of the American Public's Perceptions and Knowledge about Antibiotic Resistance. Open Forum Infectious Diseases. Oxford: Oxford University Press; 2016.

28. Mazińska B, Strużycka I, Hryniewicz W. Surveys of public knowledge and attitudes with regard to antibiotics in Poland: did the European antibiotic awareness day campaigns change attitudes? PLoS One. 2017;12(2):e0172146. doi:10.1371/journal.pone.0172146

29. Pereko DD, Lubbe MS, Essack SY. Public knowledge, attitudes and behaviour towards antibiotic usage in Windhoek, Namibia. $S$ Afr J Infect Dis. 2015;30(4):134-137. doi:10.1080/23120053.2015.1107290

30. Auta A, Banwat SB, David S, Dangiwa DA, Ogbole E, Tor-Anyiin AJ. Antibiotic use in some Nigerian communities: knowledge and attitudes of consumers. Trop J Pharm Res. 2013;12(6):1087-1092. doi:10.4314/tjpr.v12i6.33

31. Belkina T, Al Warafi A, Eltom EH, Tadjieva N, Kubena A, Vlcek J. Antibiotic use and knowledge in the community of Yemen, Saudi Arabia, and Uzbekistan. J Infect Dev Ctries. 2014;8(4):424-429. doi: $10.3855 /$ jidc. 3866

32. Rouusounides A, Papaevangelou V, Hadjipanayis A, et al. Descriptive study on parents' knowledge, attitudes and practices on antibiotic use and misuse in children with upper respiratory tract infections in Cyprus. Int $J$ Environ Res Public Health. 2011;8 (8):3246-3262. doi:10.3390/ijerph8083246

33. Mira J, Navarro I, Huttner B, et al. What do Spaniards read about the prudent use of anti-microbial agents and what do they really do? Psychol Health Med. 2014;19(2):201-210. doi:10.1080/13548506.2013.793370 


\section{Publish your work in this journal}

Infection and Drug Resistance is an international, peer-reviewed openaccess journal that focuses on the optimal treatment of infection (bacterial, fungal and viral) and the development and institution of preventive strategies to minimize the development and spread of resistance. The journal is specifically concerned with the epidemiology of

antibiotic resistance and the mechanisms of resistance development and diffusion in both hospitals and the community. The manuscript management system is completely online and includes a very quick and fair peerreview system, which is all easy to use. Visit http://www.dovepress.com/ testimonials.php to read real quotes from published authors. 